\title{
Effect of Diphenylhydantoin on Cortisol Metabolism in Man *
}

\author{
Emile E. Werk, Jr., Joseph MacGee, and Leon J. Sholiton \\ (From the Metabolism Section, Veterans Administration Hospital, and the University of \\ Cincinnati College of Medicine, Cincinnati, Ohio)
}

During a study of cortisol metabolism in advanced cancer and other disease states (1), we observed in patients receiving $\mathrm{DPH}^{1}$ therapy for convulsive seizures an abnormal pattern of excretion of cortisol metabolites in urine. This abnormal pattern was characterized by increased urinary output of the polar unconjugated metabolite 6-OHF, suggesting an interference with extraadrenal metabolism of cortisol by $\mathrm{DPH}$.

We wished to pursue this finding in more detail for two reasons: 1) An interrelationship among convulsive seizures, the anticonvulsant action of $\mathrm{DPH}$, and pituitary-adrenal function has been demonstrated by several investigators, but interpretation of this is unclear. Woodbury, Timiras, and Vernadakis have shown that cortisol and $\mathrm{DPH}$ are antagonistic in their effect on brain excitability in rats; treatment with cortisol enhances, whereas DPH depresses, brain excitability (2). These investigators believed that $\mathrm{DPH}$ administration to rats stimulates adrenocortical secretion,

\footnotetext{
* Submitted for publication January 22, 1964 ; accepted May 28, 1964.

Reported in abstract form in Clinical Research 1963, 11, 230 .

† Present address: Christ Hospital, Cincinnati, Ohio.

1 Glossary of trivial names and abbreviations: diphenylhydantoin $(\mathrm{DPH})=5,5^{\prime}$-diphenylhydantoin ; 6-hydroxycortisol $(6-\mathrm{OHF})=6 \alpha(\beta), 11 \beta, 17 \alpha, 21$ - tetrahydroxy -4 pregnene-3,20-dione ; 17 -OHCS = 17-hydroxycorticosteroids; $\mathrm{ACTH}=$ adrenocorticotrophic hormone; methopyrapone (Metopirone, Ciba Pharmaceutical Co., Summit, N. J.) =2-methyl-1,2-di-(3-pyridyl)-1-propanone. Tetrahydro derivatives: $\mathrm{THF}$ (tetrahydrocortisol) $=3 \alpha, 11 \beta$, $17 \alpha, 21$-tetrahydroxy-5 $\beta$-pregnan-20-one ; allo-THF (allotetrahydrocortisol) $=3 \alpha, 11 \beta, 17 \alpha, 21$-tetrahydroxy- $5 \alpha$-pregnan-20-one; THE (tetrahydrocortisone) $=3 \alpha, 17 \alpha, 21$-trihydroxy-5 $\beta$-pregnan-11,20-dione. $\quad$ Cortol $=3 \alpha, 11 \beta, 17 \alpha, 20 \alpha$ ( $\beta$ ), 21 -pentahydroxy-5 $\beta$-pregnane; cortolone $=3 \alpha, 17 \alpha, 20 \alpha$ $(\beta), 21$-tetrahydroxy-5 $\beta$-pregnan-11-one ; $17-\mathrm{KS}=17-\mathrm{ke}-$ tosteroids ; 11 -hydroxyetiocholanolone $=3 \alpha, 11 \beta$-dihydroxy$5 \beta$-androstan-17-one; dehydroisoandrosterone $=3 \beta$-hy droxy-5-androstene-17-one ; TPNH $=$ reduced triphosphopyridine nucleotide; o, $\mathrm{p}^{\prime} \mathrm{DDD}=2,2$-bis (2-chlorophenyl,4chlorophenyl) 1,1-dichloroethane.
}

since $a$ ) adrenal hypertrophy was observed in intact rats and $b$ ) in adrenalectomized rats treated with $\mathrm{DPH}$ a more profound decrease in brain excitability was demonstrated than in intact rats. Goncharov has observed that acute administration of DPH to dogs and guinea pigs increases adrenocortical output of cortisol (3). Reports by Staple (4) and Bonnycastle and Bradley (5) have, however, indicated an inhibition of pituitary-adrenal secretion after chronic DPH treatment of mice and rats.

In humans also cortisol has been shown to enhance brain excitability (6). After chronic DPH therapy to patients, excretion of corticosteroids in urine is reported to decrease $(7,8)$ after an initial increase ( 7$)$. These findings have led to the suggestion that the decrease in brain excitability induced by $\mathrm{DPH}$ might be mediated partially through adrenocortical suppression. However, levels of 17-OHCS in plasma from patients treated with $\mathrm{DPH}$ are usually normal $(8,9)$, as are responses to $\mathrm{ACTH}(8,9)$ and rates of disappearance from plasma of infused cortisol (8). These observations detract from the possibility that direct adrenocortical suppression plays a significant role in therapeutic effectiveness of DPH. Recently, however, Krieger has demonstrated that control subjects treated with DPH manifest a reduced response in the methopyrapone test, which suggests an interference with ACTH release (10).

2) The increased excretion of 6-OHF produced by $\mathrm{DPH}$ appears to be similar to that we have observed in patients with advanced cancer and certain terminal illnesses (1) as well as to that reported after estrogen therapy (11), during pregnancy (12), and in newborn infants (13).

Thus we hoped that further investigation into the nature of this alteration in cortisol metabolism induced by $\mathrm{DPH}$ would contribute information bearing on the two aforementioned problems. The purpose of this paper is to describe results of 
studies dealing with in vivo administration of $\mathrm{DPH}$ to human subjects.

\section{Methods}

Subjects studied were normal volunteers and patients in the Veterans Administration Hospital, Cincinnati, Ohio. DPH was administered as the commercially available product Dilantin, ${ }^{2}$ given in divided doses two or three times per day. Twenty-four-hour urine collections were obtained on ice and samples frozen until subsequent chemical analysis, a period of up to several weeks.

The radioactive cortisol-4-C ${ }^{14}$ (approximate SA, $69 \mu \mathrm{c}$ per $\mathrm{mg}$ ) was obtained commercially. ${ }^{3}$ Radio paper chromatography of this material demonstrated only one radioactive peak with a mobility comparable to cortisol. The cortisol-4-C $\mathrm{C}^{14}, 0.5 \mu \mathrm{c}$, dissolved in 1 to $2 \mathrm{ml}$ of ethanol, was diluted with $150 \mathrm{ml}$ of normal saline and infused intravenously over 10 to 15 minutes, followed by a flushing of the bottle and tubing with another $150 \mathrm{ml}$ of saline. The infusions were given at about 9 a.m. Twenty-four-hour urine collections were begun just before the infusion.

ACTH gel was administered intramuscularly, $40 \mathrm{U}$ at 9 a.m. and 1 p.m. Urine was collected for 24 hours, 8 a.m. to 8 a.m.

Chemical methods. Analysis of 17-OHCS in urine was performed according to the general procedure of Silber and Porter (14) with certain modifications. In preparation for hydrolysis the urinary sample was diluted $50 \%$ with distilled water, adjusted to $\mathrm{pH} 4.8$ with acetate buffers, and a small amount of chloroform added. $\beta$-Glucuronidase (Ketodase) ${ }^{4}$ was added initially at a concentration of $500 \mathrm{U}$ per $\mathrm{ml}$ of urine and later at higher concentrations as described in the Results. Butanol (0.7 $\mathrm{ml}$ ) was added to a sample of chloroform extract (20 $\mathrm{ml}$ ) before extraction with phenylhydrazine color reagent. Color development was allowed to proceed overnight at room temperature to minimize differences in chromogenic intensity between THF and THE (15). Optical density was read in a Beckman DU spectrophotometer at three wave lengths, 368,408 , and $448 \mathrm{~m} \mu$, the final calculation being made on the basis of an Allen correction factor. All samples had a peak reading at the middle wave length of $408 \mathrm{~m} \mu$. A sulfuric acid blank was not found to be necessary.

Determination of 6-OHF in urine was performed according to the general method of Frantz, Katz, and Jailer (16) with modifications as follows: A sample of urine equal to $5 \%$ of the 24-hour urine output was buffered with $0.2 \mathrm{M}$ acetic acid and $0.2 \mathrm{M}$ sodium acetate to $\mathrm{pH}$ 4.8. Sodium sulfate, $20 \%$ by weight, was added. Extraction with ethyl acetate and washes with alkali and acid were performed as described by the above

\footnotetext{
2 Parke, Davis, Detroit, Mich.

${ }^{3}$ New England Nuclear Corp., Boston, Mass.

${ }^{4}$ Warner-Chilcott Div., Morris Plains, N. J.
}

workers. An atmosphere of nitrogen, however, was not found necessary. After evaporation of the ethyl acetate in vacuo, the final extract was made up to a volume of $10 \mathrm{ml}$ of ethyl acetate: methanol mixture (1:1). Samples of this were chromatographed on strips of Whatman, $3 \mathrm{MM}$ paper, $3 \mathrm{~cm}$ wide, in the solvent system, ethyl acetate : chloroform : methanol : water, $1: 3: 2: 2$, for 3 to 4 hours. Quantitation was done routinely by densitometry of the strip after staining with blue tetrazolium (17) and was satisfactory between 5 and $30 \mu \mathrm{g}$ per paper strip. If an unknown sample was found to contain $30 \mu \mathrm{g}$ or more, a smaller amount of the extract was rechromatographed. Initially, standards of pure $6 \beta-\mathrm{OHF}$ were run simultaneously. We found, however, that standard curves were reproducible from day to day, and because of limited supply of pure $6 \beta-\mathrm{OHF}$, standards were run only occasionally as a check. Before staining with blue tetrazolium the paper strips were viewed under ultraviolet light (UV) to check for UV absorption of 6-OHF. Rarely we noted, from urine samples with considerable pigment, that there was strong UV absorption and subsequently only minimal staining by the blue tetrazolium reaction. When such was the case, separate samples were chromatographed after further purification by solvent partition (16). We have studied in detail the precision and accuracy of this method for measuring 6-OHF. The mean difference between duplicate analyses was $6 \%$. On comparing the densitometric method of quantitation versus elution from the paper and the phenylhydrazine-sulfuric acid color reaction, the mean difference between multiple samples was found to be $11 \%$. Recovery of $6 \beta$-OHF added to several urine samples and quantitated by densitometry averaged $73 \%$. Final results were corrected for this loss. Further identification of 6-OHF from urine extracts was performed in several instances by eluting unstained 6-OHF after chromatography, and examining 1) UV absorption spectra in methanol and 2) absorption spectra after reaction with sulfuric acid. These agreed with pure standards. Both $6 \alpha-\mathrm{OHF}$ and $6 \beta-\mathrm{OHF}$ exhibit absorption maxima at $236 \mathrm{~m} \mu$ in methanolic solution. The sulfuric acid absorption curves of these two compounds, however, were different, and the two compounds could be recognized accordingly. $6 \alpha-\mathrm{OHF}$ has a peak at 280 $\mathrm{m} \mu$, whereas this is absent with $6 \beta-\mathrm{OHF}$. Conversely, $6 \beta$-OHF has a peak at $335 \mathrm{~m} \mu$, and $6 \alpha$-OHF does not. In several instances the amounts of $6 \alpha-\mathrm{OHF}$ and $6 \beta-\mathrm{OHF}$ were quantitated by differential absorption curves. The amount of $6 \alpha-\mathrm{OHF}$ varied from a trace to $56 \%$ without any correlation with diagnosis or treatment of the patient. Quantitating these separate isomers did not seem to be of value. Results for $6-\mathrm{OHF}$ pertain to the total of $6 \alpha$ - and $6 \beta-O H F$. Another more polar compound was usually observed running about halfway between the origin and 6-OHF on the paper strips. This compound reacted with blue tetrazolium and absorbed UV light. The concentration of this substance correlated directly with that of 6-OHF. As demonstrated subsequently in 
the studies with cortisol-4- $\mathrm{C}^{14}$, this polar unknown compound was a metabolite of cortisol, but its identification has not been accomplished. Incubation of several urine samples with $\beta$-glucuronidase before extraction did not increase the yield of $6-\mathrm{OHF}$, which is similar to the observation of Frantz and associates (16).

Determination of THF, allo-THF, and THE. These metabolites were analyzed from chloroform extracts of $\beta$-glucuronidase hydrolyzed urine samples (10 to $40 \mathrm{ml}$ ). Extracts were chromatographed on paper strips in duplicate for 24 hours in the system, toluene: methanol: water $(16: 3: 1)$. THF, allo-THF, and THE were located by staining a small inner strip with blue tetrazolium. The three metabolites were eluted from the remaining paper with absolute methanol, and the phenylhydrazinesulfuric acid color reaction was performed on the eluate. Standards of THE and THF were chromatographed on adjacent strips, and the unknown samples were quantitated according to the standards. Final calculations also took into account an average loss from extraction as determined by adding standards to various urine portions. Duplicate samples through the entire procedure agreed within $10 \%$.

17-KS and creatinine. Levels of $17-\mathrm{KS}$ were determined by the procedure of Drekter and co-workers (18). Urinary levels of creatinine were measured according to the technique of Folin and $\mathrm{Wu}$ (19).

Procedures with cortisol-4- $C^{14}$. $\beta$-Glucuronidase hydrolysis was similar to that described under the chemical analysis for 17-OHCS in urine. Acid hydrolysis was performed by acidification of the urine to $\mathrm{pH} 1$ with $50 \%$ sulfuric acid and incubation for 24 hours at $37^{\circ} \mathrm{C}$ in the dark. When no hydrolysis was performed, urine was buffered with acetate to $\mathrm{pH} 4.8$ before solvent extraction. Extraction with chloroform or ethyl acetate was performed in a manner similar to that described for the chemical method for $17-\mathrm{OHCS}$ and 6-OHF, respectively. Solvents were evaporated on vacuum flash evaporators or in vacuo under a stream of filtered air and made up to volume with absolute methanol.

In the fractional separation by paper chromatography (Table II), ethyl acetate extracts of urine samples (5 to $7 \%$ of 24 -hour output), hydrolyzed by $\beta$-glucuronidase, were chromatographed on paper in the system described under the chemical procedure for 6-OHF. The mobile phase was allowed to run to the edge of the paper, allowing separation of six major fractions as predetermined by chromatographing appropriate standards. With each run of urine extracts two adjacent strips with standards were used and stained with blue tetrazolium and phosphomolybdic acid, respectively. A $2-\mathrm{mm}$ wide strip also was cut from the center of each strip containing a urine extract and stained with blue tetrazolium. As shown in Table II, six major fractions could be identified; they were divided, cut up into smaller pieces, and eluted with absolute methanol. The methanol extracts were evaporated and made up to a known volume with methanol. Samples of each fraction were taken for counting of $\mathrm{C}^{14}$. After removing the sample from frac- tion six, the residual extract was evaporated to dryness and subsequent chromatography performed on a Florisil column to separate the $17-\mathrm{KS}$ and the tetrahydro compounds with $4 \%$ and $25 \%$ concentrations of methanol in chloroform, respectively (20). The column eluates were evaporated, made up to volume with methanol, and samples taken for counting $\mathrm{C}^{14}$.

Cortisol secretion rates (CSR) were determined from chloroform extracts of urine samples (10 to $50 \mathrm{ml}$ ) incubated with $\beta$-glucuronidase. The extracts were chromatographed on paper strips in duplicate for 24 hours in the system, toluene: methanol: water $(16: 3: 1)$. THF and THE were located by staining a thin inner strip with blue tetrazolium, and the THF and THE were eluted with methanol. The phenylhydrazine-sulfuric acid color reaction was performed on one sample of the eluate and $\mathrm{C}^{\mathbf{1 4}}$ counted on another. The final specific activities of THF and THE usually agreed within $10 \%$. In urine samples from two of the six patients, the specific activities of THF and THE varied widely despite rechromatography. In these instances new extracts were chromatographed in the system, isoöctane: tertiary butanol: water $(10: 5: 9)$, the THF and THE eluted, reduced with potassium borohydride, and oxidized with periodic acid. The final product, 11-hydroxyetiocholanolone, in each case was chromatographed on separate paper strips in the system, isoöctane: toluene: methanol: water $(3: 1: 3: 1)$ and eluted with methanol. Specific activity was determined by the Zimmerman reaction and counting on respective samples. Specific activities of the final 11-hydroxyetiocholanolone preparations, expressed as $\mathrm{THF}$ and $\mathrm{THE}$, agreed within $10 \%$. In four subjects, during $\mathrm{DPH}$ therapy, specific activities of 6-OHF were determined by the same method to isolate $6-\mathrm{OHF}$ as in the chemical determination of this metabolite. Instead of densitometry, however, the 6-OHF was eluted from the paper chromatographic strip and specific activity determined by the phenylhydrazine-sulfuric acid color reaction and counting of the $\mathrm{C}^{\mathbf{1 4}}$. The specific activities (disintegrations per minute $\times 10^{-4}$ per micromole) of the $6-\mathrm{OHF}$ in these four instances were $2.96,0.86,1.64$, and 1.36 and compared closely to the average specific activities of the THF and THE, 2.86, 0.92, 1.66, and 1.31, respectively. CSR was calculated by dividing the average specific activities of the two or three isolated metabolites into dose of radioactivity injected.

All counting of $\mathrm{C}^{14}$ was performed on a Packard TriCarb liquid scintillation spectrometer with a usual efficiency of about $60 \%$. Methanolic samples, 0.1 to $0.3 \mathrm{ml}$, of the various eluates were added to $10 \mathrm{ml}$ of toluene scintillation solution [4 $\mathrm{g}$ of 2,5-diphenyloxazole and $100 \mathrm{mg}$ of 1,4-bis-2-(5-phenyloxazolyl)-benzene per L of toluene]. Quenching was corrected for by adding $\mathrm{C}^{14}$ standards to these samples, recounting, and calculating accordingly. All counting was sufficiently long to minimize error to $5 \%$ or less. Counting of radioactivity in whole urine was done according to the technique outlined by Flood and associates (21). 


\section{Results}

Inhibition of in vitro $\beta$-glucuronidase hydrolysis in urine from patients receiving $D P H$. During the course of this investigation we noted that the amount of radioactivity extracted with ethyl acetate or chloroform from urine of patients receiving DPH and cortisol-4- $\mathrm{C}^{\mathbf{1 4}}$ was unexpectedly low. These urine samples had been incubated with $\beta$-glucuronidase at a concentration of $500 \mathrm{U}$ per $\mathrm{ml}$ of urine before extraction. The possibility that the poor recoveries of radioactivity were due to insufficient hydrolysis of the cortisol metabolites by $\beta$-glucuronidase was tested by adding increasing amounts of enzyme to urine samples that were subsequently extracted with chloroform or ethyl acetate. ${ }^{5}$ As can be seen in Figure 1, maxi-

5 The procedure for ethyl acetate extraction, as referred to throughout this paper, always included the addition of $20 \%$ sodium sulfate to urine before extraction.

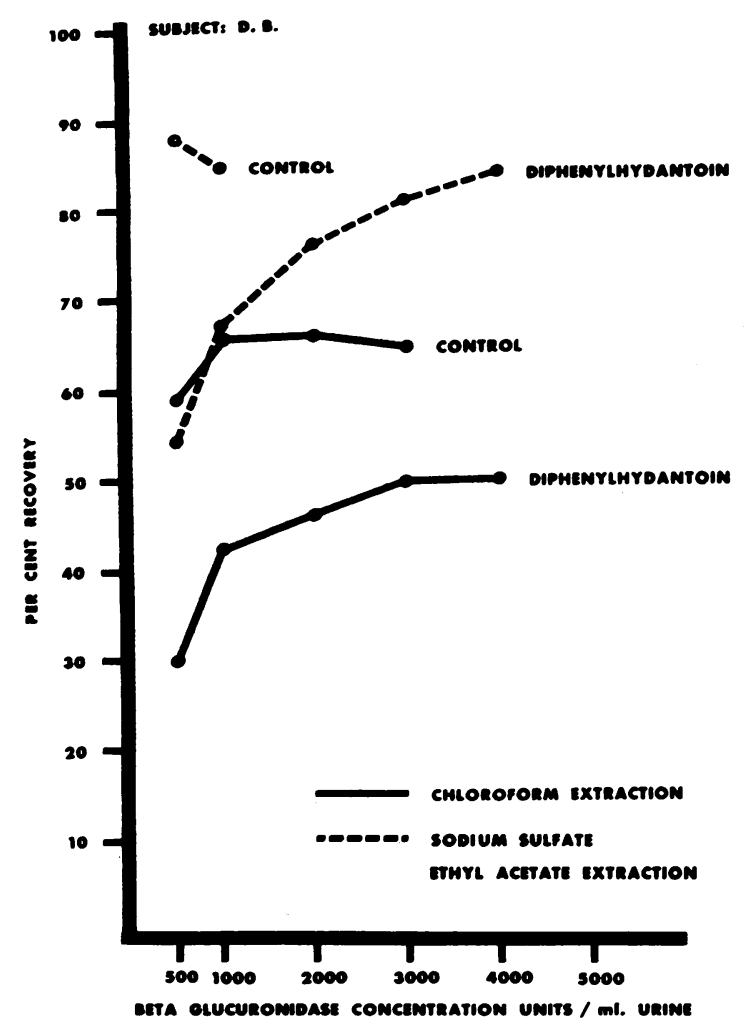

mal recovery of radioactivity was not achieved in urine from two normal subjects treated with $\mathrm{DPH}$ until the enzyme concentration approached 4,000 $\mathrm{U}$ per $\mathrm{ml}$ of urine, employing either chloroform or ethyl acetate for extraction, whereas in urine collected during control periods maximal hydrolysis was obtained with an enzyme concentration of $1,000 \mathrm{U}$ per $\mathrm{ml}$ of urine.

It may also be noted in Figure 1 that when chloroform extraction was employed, recovery of radioactivity from urine during the $\mathrm{DPH}$ treatment period was considerably below that from urine during the control period, despite maximal enzyme concentration. This is consistent with an absolute decrease in cortisol metabolites in the chloroform-extractable fraction induced by $\mathrm{DPH}$, as will be re-emphasized subsequently.

The effect of increasing concentration of $\beta$-glucuronidase during hydrolysis of urine was also evaluated by employing the routine chloroform

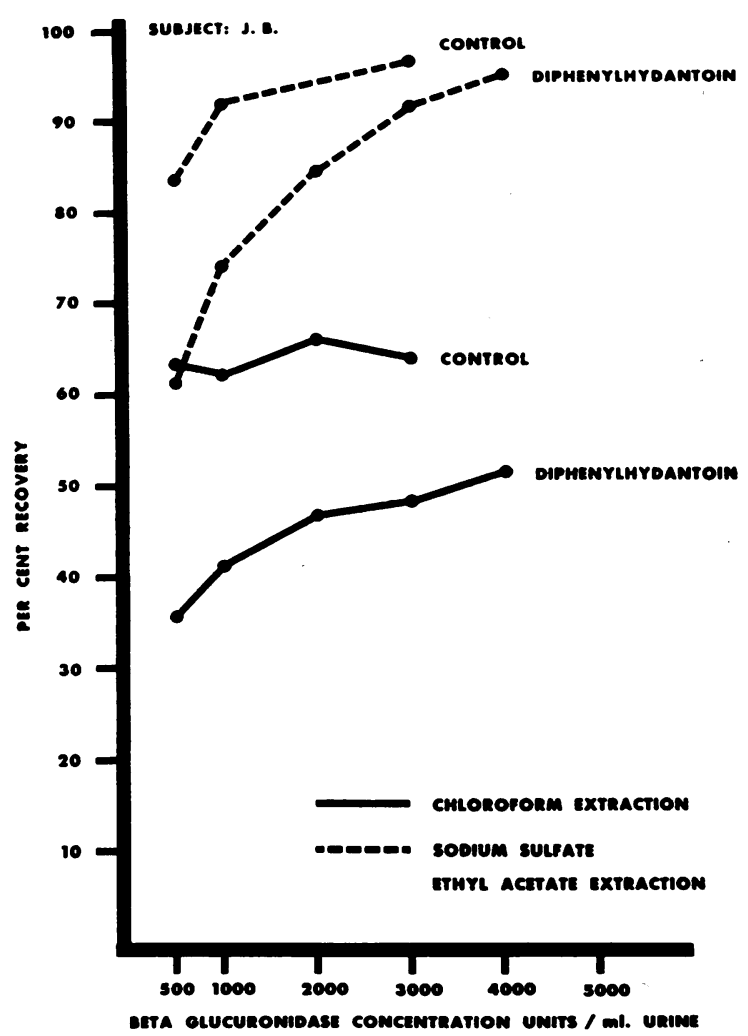

Fig. 1. EFFECT OF $\beta$-GLUCURONIDASE CONCENTRATION DURING HYDROLYSIS ON RECOVERY OF CORTISOL-4-C ${ }^{14}$ METABOLITES FROM URINE OF DIPHENYLHYDANTOIN (DPH) -TREATED NORMAL SUBJECTS. Cortisol-4-C ${ }^{14}$ was administered to each subject during a control period and again during therapy with DPH as outlined in Table IV, pertaining to cortisol secretion rates determined from the same 24-hour urine collections. The scale on the ordinate axis is expressed as percentage of recovery of radioactivity to that measured in whole urine. 


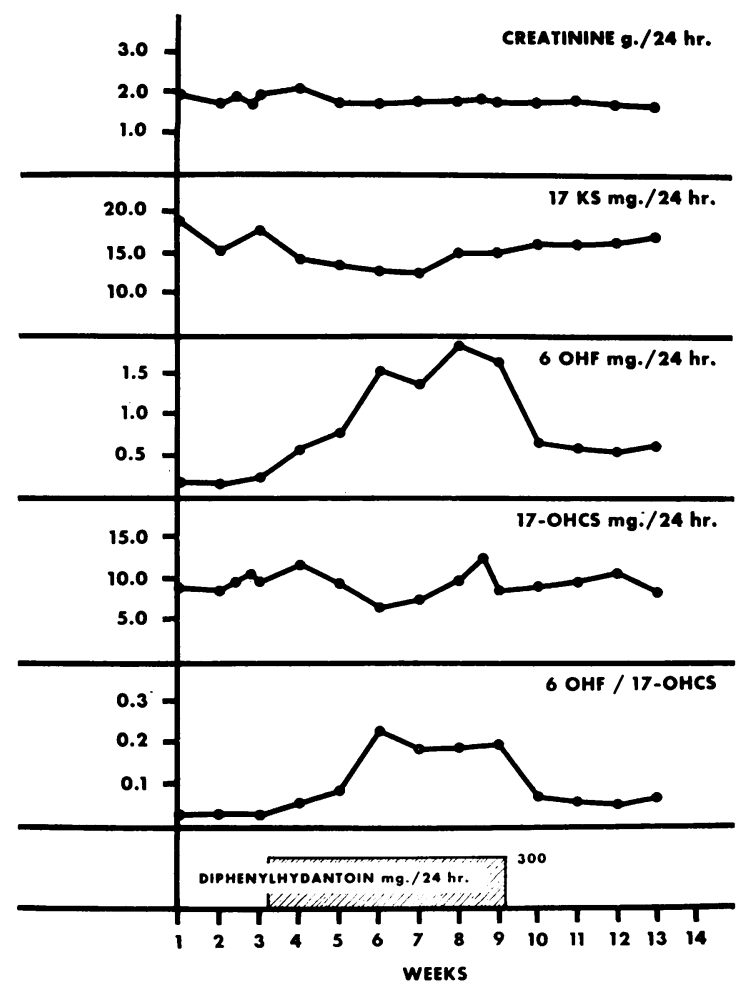

Fig. 2. EFFECT OF DPH ON STEROID EXCRETION IN URINE OF NORMAL SUBJECT D.B., 24-YEAR-OLD MALE.

extraction chemical method for 17-OHCS. The $17-\mathrm{OHCS}$ values averaged $45 \%$ higher with an enzyme concentration of $4,000 \mathrm{U}$ per $\mathrm{ml}$ than with $500 \mathrm{U}$ per $\mathrm{ml}$ in four subjects receiving $\mathrm{DPH}$. During the control period in these four subjects, the chemical values using an enzyme concentration of $1,000 \mathrm{U}$ per $\mathrm{ml}$ of urine were slightly higher than with $500 \mathrm{U}$ per $\mathrm{ml}$, average increase $16 \%$.

Thus, in all analyses pertaining to $\beta$-glucuronidase hydrolysis, concentration of enzyme employed was $1,000 \mathrm{U}$ per $\mathrm{ml}$ of urine from control periods and 4,000 $\mathrm{U}$ per $\mathrm{ml}$ of urine from samples of subjects receiving $\mathrm{DPH}$. Urine samples that had been collected early in the study and initially analyzed with a lower enzyme concentration were repeated, or in a few instances an average correction factor, based upon the previously mentioned data, was applied.

Steroid excretion. In Figure 2 weekly steroid excretion is presented for a representative normal subject given DPH, $300 \mathrm{mg}$ per day for 6 weeks. The most marked effect of DPH was gradually increasing the daily output of 6-OHF from about $0.2 \mathrm{mg}$ up to $1.9 \mathrm{mg}$. On the other hand, excre- tion of 17-OHCS and 17-KS in urine decreased slightly. The alteration in cortisol metabolism can be expressed by the ratio of 6-OHF:17OHCS, which increased tenfold in this subject.

In Figure 3 similar data are shown for a patient with brain trauma who had intermittent convulsive seizures. Initial urine samples were obtained when he was receiving $\mathrm{DPH}$ treatment. There was an abnormally large output of $6-\mathrm{OHF}$, $7.2 \mathrm{mg}$ per day. After DPH had been discontinued, excretion of 6-OHF decreased to normal range, as did the ratio $6-\mathrm{OHF}: 17-\mathrm{OHCS}$. Subsequently two other courses of $\mathrm{DPH}$ were given, and in each a progressive rise in excretion of $6-\mathrm{OHF}$ ensued. Interestingly, output of 17 OHCS also increased up to a maximum at one point of $19.8 \mathrm{mg}$ per day from the mean baseline level of $6.4 \mathrm{mg}$ per day. The ratios of $6-\mathrm{OHF}: 17-\mathrm{OHCS}$ were markedly abnormal, and during one collection within the first week of discontinuing $\mathrm{DPH}$ the second time, daily output of 6-OHF (11.4 mg) was considerably higher than excretion of 17-OHCS ( $6 \mathrm{mg})$. The degree of alteration in steroid excretion demonstrated by this debilitated patient, in response to $\mathrm{DPH}$ therapy, was much greater than in any of the other subjects studied.

It may be noted also from Figure 3 that this patient was given a 3 -week course of stilbestrol, which had been reported previously to increase

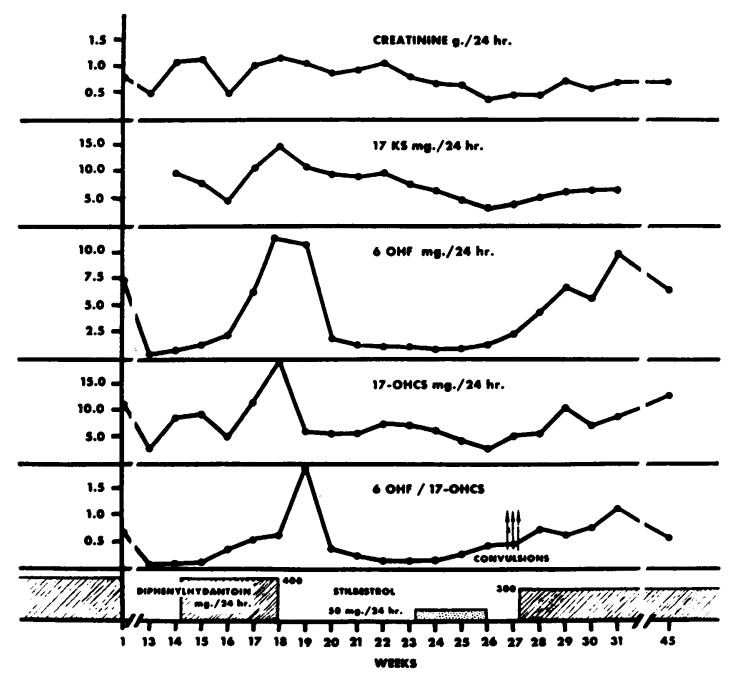

Fig. 3. EFFect OF DPH ON STEROID EXCRETION IN urine of Patient F.J., 65-year-old male. Diagnosis: old brain trauma. 
TABLE I

Effect of DPH administration on steroid excretion in urine

\begin{tabular}{|c|c|c|c|c|c|c|c|c|}
\hline \multirow[b]{2}{*}{$\begin{array}{l}\text { Subject, } \\
\text { age }\end{array}$} & \multirow{2}{*}{\multicolumn{2}{|c|}{ Diagnosis, weight }} & \multirow[b]{2}{*}{$\begin{array}{l}\text { Period of urine } \\
\text { collections } \dagger\end{array}$} & \multicolumn{5}{|c|}{ 24-hour excretions* } \\
\hline & & & & 6-OHF & 17-OHCS & $\frac{6-\mathrm{OHF}}{17-\mathrm{OHCS}}$ & 17-KS & $\begin{array}{l}\text { Creat- } \\
\text { inine }\end{array}$ \\
\hline & & $\mathrm{kg}$ & & $m g$ & $m g$ & & $m g$ & $g$ \\
\hline \multicolumn{9}{|c|}{ Male subjects } \\
\hline $\begin{array}{c}\text { D.B. } \\
24\end{array}$ & Normal & 66 & $\begin{array}{l}\text { Control (5) } \\
\text { DPH, } 300 \mathrm{mg} / \mathrm{day} \text {, } \\
\text { 3-6 weeks (5) }\end{array}$ & $\begin{array}{l}0.16 \\
1.60\end{array}$ & $\begin{array}{l}9.4 \\
8.9\end{array}$ & $\begin{array}{l}0.02 \\
0.20\end{array}$ & $\begin{array}{l}17.4 \\
13.9\end{array}$ & $\begin{array}{l}1.84 \\
1.76\end{array}$ \\
\hline $\begin{array}{r}\text { J.B. } \\
24\end{array}$ & Normal & 100 & $\begin{array}{l}\text { Control (4) } \\
\text { DPH, } 400 \mathrm{mg} / \mathrm{day}, \\
\text { 3-7 weeks (7) }\end{array}$ & $\begin{array}{l}0.50 \\
1.44\end{array}$ & $\begin{array}{l}13.4 \\
13.3\end{array}$ & $\begin{array}{l}0.04 \\
0.11\end{array}$ & $\begin{array}{l}22.3 \\
15.8\end{array}$ & $\begin{array}{l}2.56 \\
2.49\end{array}$ \\
\hline$\underset{25}{\text { R.M. }}$ & Normal & 82 & $\begin{array}{l}\text { Control (3) } \\
\text { DPH, } 400 \mathrm{mg} / \mathrm{day} \text {, } \\
5 \text { weeks (3) }\end{array}$ & $\begin{array}{l}0.49 \\
2.30\end{array}$ & $\begin{array}{r}10.5 \\
7.8\end{array}$ & $\begin{array}{l}0.05 \\
0.30\end{array}$ & $\begin{array}{l}20.7 \\
17.7\end{array}$ & $\begin{array}{l}2.24 \\
2.24\end{array}$ \\
\hline$\underset{25}{G . B .}$ & Normal & 95 & $\begin{array}{l}\text { Control (3) } \\
\text { DPH, } 400 \mathrm{mg} / \mathrm{day} \\
5 \text { weeks }(2)\end{array}$ & $\begin{array}{l}0.43 \\
1.00\end{array}$ & $\begin{array}{l}12.8 \\
12.0\end{array}$ & $\begin{array}{l}0.03 \\
0.08\end{array}$ & $\begin{array}{l}21.6 \\
19.0\end{array}$ & $\begin{array}{l}2.65 \\
2.31\end{array}$ \\
\hline$\underset{24}{\text { A.G. }}$ & Normal & 93 & $\begin{array}{l}\text { Control (3) } \\
\text { DPH, } 400 \mathrm{mg} / \mathrm{day} \text {, } \\
6 \text { weeks }(3)\end{array}$ & $\begin{array}{l}0.29 \\
1.52\end{array}$ & $\begin{array}{l}10.9 \\
12.6\end{array}$ & $\begin{array}{l}0.03 \\
0.12\end{array}$ & $\begin{array}{l}16.7 \\
14.5\end{array}$ & $\begin{array}{l}2.37 \\
2.64\end{array}$ \\
\hline S.C. & \multicolumn{2}{|c|}{$\begin{array}{l}\text { Paraplegia } \\
73\end{array}$} & $\begin{array}{l}\text { Control (5) } \\
\text { DPH, } 300 \mathrm{mg} / \mathrm{day}, \\
\text { 3-8 weeks (8) }\end{array}$ & $\begin{array}{l}0.25 \\
1.22\end{array}$ & $\begin{array}{l}8.7 \\
6.3\end{array}$ & $\begin{array}{l}0.03 \\
0.21\end{array}$ & $\begin{array}{r}14.1 \\
8.8\end{array}$ & $\begin{array}{l}1.16 \\
0.92\end{array}$ \\
\hline F.J. & \multicolumn{2}{|c|}{$\begin{array}{c}\text { Brain trauma } \\
\mathbf{5 0}\end{array}$} & $\begin{array}{l}\text { Control (4) } \\
\text { DPH, } 300 \mathrm{mg} / \mathrm{day} \\
2-4 \text { weeks (3) }\end{array}$ & $\begin{array}{l}0.78 \\
6.70\end{array}$ & $\begin{array}{r}6.4 \\
12.1\end{array}$ & $\begin{array}{l}0.11 \\
0.51\end{array}$ & $\begin{array}{l}8.8 \\
9.8\end{array}$ & $\begin{array}{l}0.84 \\
0.86\end{array}$ \\
\hline R.S. $\neq$ & \multicolumn{2}{|c|}{$\begin{array}{r}\text { Tuberculosis } \\
77\end{array}$} & $\begin{array}{l}\text { Control (4) } \\
\text { DPH, } 300 \mathrm{mg} / \text { day, } \\
\text { 2-3 weeks (2) }\end{array}$ & $\begin{array}{l}0.14 \\
1.31\end{array}$ & $\begin{array}{l}6.3 \\
6.3\end{array}$ & $\begin{array}{l}0.02 \\
0.22\end{array}$ & $\begin{array}{l}13.2 \\
11.0\end{array}$ & $\begin{array}{l}1.51 \\
1.28\end{array}$ \\
\hline$\underset{68}{\text { L.H. }}$ & \multicolumn{2}{|c|}{$\begin{array}{l}\text { Addison's } \\
\text { disease, tuberculosis } \\
\text { (30 mg F/day) } \\
64\end{array}$} & $\begin{array}{l}\text { Control (3) } \\
\text { DPH, } 300 \mathrm{mg} / \text { day, } \\
2 \text { weeks (2) }\end{array}$ & $\begin{array}{l}0.12 \\
0.54\end{array}$ & $\begin{array}{l}9.9 \\
7.0\end{array}$ & $\begin{array}{l}0.01 \\
0.08\end{array}$ & & $\begin{array}{l}1.48 \\
0.86\end{array}$ \\
\hline W.G. & \multicolumn{2}{|c|}{$\begin{array}{l}\text { Adrenalectomized } \\
\text { bilaterally }(30 \mathrm{mg} \\
\text { F/day) } \\
\qquad 95\end{array}$} & $\begin{array}{l}\text { Control (3) } \\
\text { DPH, } 400 \mathrm{mg} / \text { day, } \\
5 \text { weeks (4) }\end{array}$ & $\begin{array}{l}0.49 \\
1.52\end{array}$ & $\begin{array}{l}16.3 \\
13.0\end{array}$ & $\begin{array}{l}0.03 \\
0.12\end{array}$ & $\begin{array}{l}10.9 \\
11.0\end{array}$ & $\begin{array}{l}2.31 \\
2.15\end{array}$ \\
\hline \multicolumn{9}{|c|}{ Female subject } \\
\hline $\begin{array}{l}\text { D.W. } \\
24\end{array}$ & Normal & 57 & $\begin{array}{l}\text { Control (4) } \\
\text { DPH, } 300 \mathrm{mg} / \text { day, } \\
2-4 \text { weeks (3) }\end{array}$ & $\begin{array}{l}0.24 \\
1.91\end{array}$ & $\begin{array}{l}5.4 \\
3.9\end{array}$ & $\begin{array}{l}0.04 \\
0.48\end{array}$ & $\begin{array}{r}11.2 \\
8.4\end{array}$ & $\begin{array}{l}1.34 \\
1.32\end{array}$ \\
\hline
\end{tabular}

* Levels shown represent averages of several determinations during the period indicated; the number of determinations during each period is indicated by the number in parentheses after the period of urine collection. The first and of ten second week of collection values were not included in the DPH period, since the changes had not yet stabilized. In subjects R.M., G.B., A.G., L.H., and W.G. urines sample were collected only at the end of the period of DPH administration. See first footnote in text for key to abbreviations in all tables.

† Control periods varied from 1 to 3 weeks in the male subjects and extended over 4 weeks in the female to evaluate possible changes during the menstrual cycle.

$\ddagger$ During the administration of DPH, patient R.S. developed a toxic hepatitis manifested by anorexia, nausea, and elevated serum enzyme levels and demonstrated by liver biopsy. Recovery was prompt af ter discontinuance of all drugs. \& Patient L.H. developed severe vertigo and ataxia which probably resulted from the combination of therapy with $\mathrm{DPH}$ and isoniazid (22). Recovery was gradual after discontinuance of DPH. Urine collections were incomplete during the DPH period in this patient. 
TABLE II

Effect of DPH administration on fractionation of cortisol-4- $C^{\mathbf{1 4}}$ metabolites in urine by paper chromatographic separation after $\beta$-glucuronidase hydrolysis and ethyl acetate extraction*

\begin{tabular}{|c|c|c|c|c|c|c|}
\hline & \multicolumn{2}{|c|}{ Subject D.B. } & \multicolumn{2}{|c|}{ Subject J.B. } & \multicolumn{2}{|c|}{ Subject R.M. } \\
\hline & Control & DPH† & Control & $\mathrm{DPH}+$ & Control & $\mathrm{DPH} \dagger$ \\
\hline $\begin{array}{l}\text { Radioactivity extracted, } d p m \\
\text { Percentage of recovery }\end{array}$ & $\begin{array}{l}56,480 \\
85\end{array}$ & $\begin{array}{c}57,840 \\
87\end{array}$ & $\begin{array}{c}36,561 \\
79\end{array}$ & $\begin{array}{c}43,345 \\
82\end{array}$ & $\begin{array}{c}43,760 \\
78\end{array}$ & $\begin{array}{c}39,440 \\
73\end{array}$ \\
\hline $\begin{array}{l}\text { Radioactivity applied to } \\
\text { paper, } d p m\end{array}$ & 55,068 & 57,117 & 36,561 & 43,345 & 43,213 & 38,947 \\
\hline $\begin{array}{l}\text { Radioactivity eluted from } \\
\text { paper, } d p m \\
\text { Percentage of recovery }\end{array}$ & $\begin{array}{c}42,636 \\
77\end{array}$ & $\begin{array}{c}48,568 \\
85\end{array}$ & $\begin{array}{c}31,657 \\
87\end{array}$ & $\begin{array}{l}35,750 \\
82\end{array}$ & $\begin{array}{c}37,444 \\
87\end{array}$ & $\begin{array}{c}36,412 \\
93\end{array}$ \\
\hline $\begin{array}{l}\text { Paper fraction } \\
\text { 1) Origin to polar unknown } \\
\text { 2) Polar unknown } \\
\text { 3) Polar unknown to 6-OHF } \\
\text { 4) 6-OHF } \\
\text { 5) Cortols, cortolones } \\
\text { 6) } \ddagger \text { a) THF, allo-THF, THE } \\
\text { b) 17-KS (11 oxy) }\end{array}$ & $\begin{array}{r}1.4 \\
1.7 \\
0.4 \\
3.2 \\
16.8 \\
73.7 \\
2.4\end{array}$ & $\begin{array}{r}\mathrm{Pe} \\
0.9 \\
5.0 \\
0.8 \\
7.5 \\
14.8 \\
66.4 \\
4.2\end{array}$ & $\begin{array}{c}\text { radioa } \\
\text { otal elu } \\
0.7 \\
1.8 \\
3.3 \\
3.1 \\
17.6 \\
69.8 \\
3.6\end{array}$ & $\begin{array}{c}\text { ty in eac } \\
\text { rom pap } \\
1.3 \\
6.8 \\
3.3 \\
6.8 \\
19.0 \\
59.9 \\
2.9\end{array}$ & $\begin{array}{r}0.8 \\
2.2 \\
0.4 \\
2.0 \\
11.5 \\
73.1 \\
10.0\end{array}$ & $\begin{array}{r}1.3 \\
6.7 \\
1.0 \\
10.1 \\
12.4 \\
59.5 \\
8.9\end{array}$ \\
\hline
\end{tabular}

* All ethyl acetate extractions were performed after addition of sodium sulfate to urine sample (approximately 5 to $7 \%$ of 24-hour output), as described under Methods. The solvent system used in the paper chromatography was the same as that described in the chemical determination of 6-OHF.

$\dagger$ The dose and duration of therapy with DPH were the same as those shown in Table IV.

$\ddagger$ Further fractionated into a) and b) by Florisil column chromatography.

6-OHF excretion (11). A slight rise in 6-OHF output occurred, which was much less than that after DPH. Moreover, excretion of 17-OHCS decreased slightly, in contrast to the rise observed after DPH.

In Table I changes in steroid excretion are summarized for 11 subjects receiving DPH for 2 to 8 weeks. A consistent elevation in output of 6-OHF, ranging from 2.5 - to 10 -fold, was found in all subjects. Excretion of 17-OHCS in urine decreased slightly in 7 of the 11 subjects, increased in 2 , and was essentially unchanged in 2 . The

TABLE III

The ratios of tetrahydro cortisol metabolites in urine after $D P H$

\begin{tabular}{|c|c|c|c|c|}
\hline Subject & $\frac{\text { THF }}{\text { Total }}$ & $\frac{\text { Allo-THF }}{\text { Total }}$ & $\frac{\text { THE }}{\text { Total }}$ & $\frac{\text { THF }}{\text { THE }}$ \\
\hline \multicolumn{5}{|l|}{ D.B. } \\
\hline Control & 0.27 & 0.18 & 0.55 & 0.48 \\
\hline $\mathrm{DPH}, 300 \mathrm{mg} / \mathrm{day}, 4$ weeks & 0.32 & 0.13 & 0.55 & 0.58 \\
\hline Percentage of change & +18 & -28 & $\mathbf{0}$ & +21 \\
\hline \multicolumn{5}{|l|}{ J.B. } \\
\hline Control & 0.22 & 0.16 & 0.62 & 0.36 \\
\hline DPH, $400 \mathrm{mg} /$ day, 5 weeks & 0.33 & 0.12 & 0.55 & 0.60 \\
\hline Percentage of change & +50 & -25 & -11 & +67 \\
\hline \multicolumn{5}{|l|}{ R.M. } \\
\hline Control & 0.24 & 0.18 & 0.58 & 0.42 \\
\hline $\mathrm{DPH}, 400 \mathrm{mg} /$ day, 5 weeks & 0.34 & 0.18 & 0.48 & 0.72 \\
\hline Percentage of change & +42 & $\mathbf{0}$ & -17 & +71 \\
\hline
\end{tabular}

ratio of 6-OHF : 17-OHCS increased significantly in all subjects. Excretion of $17-\mathrm{KS}$ decreased in eight of ten subjects. Of particular interest are patients L.H. and W.G., who had adrenal insufficiency and were maintained on exogenous cortisol. The usual increase in excretion of 6-OHF and in the ratio of $6-\mathrm{OHF}: 17-\mathrm{OHCS}$ was observed in both subjects. However, the level of 17-KS did not decrease in W.G.

Subject D.W. was the only female studied, and her response was similar to that of the males but was more marked, as demonstrated by the high ratio of $6-\mathrm{OHF}: 17-\mathrm{OHCS}, 0.48$. The alterations could not be attributed to any change with the menstrual cycle.

Fractionation of cortisol-4-C $C^{\mathbf{1 4}}$ metabolites in urine after administration of cortisol-4-C $C^{14}$ in vivo. In three subjects recoveries of radioactive metabolites were studied initially according to conjugation and polarity. Separate urine samples that had received 1) no prior hydrolysis, 2) $\mathrm{pH} 1$ hydrolysis, and 3) $\beta$-glucuronidase hydrolysis were extracted with chloroform or ethyl acetate. The main changes observed consistently after DPH treatment were as follows: 1) a decrease, approximating $20 \%$, in metabolites conjugated with glucuronic acid and extracted with chloroform (as 
TABLE IV

Cortisol secretion rates $(C S R)$ : control and during DPH administration

\begin{tabular}{|c|c|c|c|c|c|c|c|c|}
\hline \multirow[b]{3}{*}{ Subject } & \multicolumn{3}{|c|}{ Control } & \multicolumn{4}{|c|}{$\mathrm{DPH}$} & \multirow{3}{*}{$\begin{array}{l}\text { Percent } \\
\text { age of } \\
\text { change }\end{array}$} \\
\hline & \multicolumn{2}{|c|}{$\begin{array}{l}\text { 17-OHCS excre- } \\
\text { tion in urine }\end{array}$} & \multirow[b]{2}{*}{ CSR } & \multirow[b]{2}{*}{ Dose } & \multicolumn{2}{|c|}{$\begin{array}{l}\text { 17-OHCS excre- } \\
\text { tion in urine }\end{array}$} & \multirow[b]{2}{*}{ CSR } & \\
\hline & Average* & $\begin{array}{l}\text { Day } \\
\text { CSR }\end{array}$ & & & Average* & $\begin{array}{l}\text { Day } \\
\text { CSR }\end{array}$ & & \\
\hline & $\mathrm{mg} / 24 \mathrm{hrs}$ & $m g / 2+h r s$ & $\mathrm{mg} / 24 \mathrm{hrs}$ & & $m g / 24 h r s$ & $\mathrm{mg} / 24 \mathrm{hrs}$ & $m g / 24 \mathrm{hrs}$ & $\%$ \\
\hline D.B. & 9.4 & 9.6 & 18 & $\begin{array}{c}300 \mathrm{mg} / \mathrm{day}, \\
5 \text { weeks }\end{array}$ & 8.9 & 12.6 & 32 & +78 \\
\hline J.B. & 13.4 & 14.4 & 24 & $400 \mathrm{mg} /$ day, & 13.3 & 13.0 & 30 & +25 \\
\hline S.C. & 8.7 & 8.4 & 18 & $\begin{array}{c}300 \mathrm{mg} / \text { day, } \\
8 \text { weeks }\end{array}$ & 6.3 & 5.1 & 27 & +50 \\
\hline A.G. & 10.9 & 12.1 & 23 & $\begin{array}{l}400 \mathrm{mg} / \mathrm{day}, \\
6 \text { weeks }\end{array}$ & 12.6 & 12.9 & 28 & +22 \\
\hline G.B. & 12.8 & 14.5 & 23 & $\begin{array}{l}400 \mathrm{mg} / \mathrm{day} \\
5 \text { weeks }\end{array}$ & 12.0 & 12.1 & 21 & -9 \\
\hline R.M. & 10.5 & 10.7 & 21 & $\begin{array}{c}400 \mathrm{mg} / \mathrm{day} \\
5 \text { weeks }\end{array}$ & 7.8 & 8.7 & 21 & 0 \\
\hline
\end{tabular}

* Average excretion of $17-\mathrm{OHCS}$ in urine for the respective period, same as shown on Table I.

may be noted from Figure 1) ; and 2) an increase, about twofold, in polar unconjugated metabolites extracted by ethyl acetate. There were no significant differences noted in unconjugated chloroform-extractable fractions or acid-hydrolyzable fractions.

In Table II changes determined by a more discrete fractionation system are depicted from urine samples of the same three subjects. In these experiments extracts of urine that had been hydrolyzed with $\beta$-glucuronidase and extracted with ethyl acetate were fractionated as described in the Methods section. The principal changes after $\mathrm{DPH}$ therapy were the decrease in tetrahydro metabolites, THF, allo-THF, and THE, and the increase in 6-OHF and an unidentified polar unknown. No consistent differences were noted in the cortol-cortolone fractions or in the $17-\mathrm{KS}$.
Excretion of tetrahydro derivatives. In view of the changes in the tetrahydro fraction, it was considered of interest to compare excretion of individual tetrahydro metabolites. The results, Table III, are expressed in terms of ratios of individual metabolites to the sum total or to each other. The ratios of THF : total and THF: THE increased during DPH therapy, whereas the ratios allo-THF : total and THE : total tended to decrease.

CSR, Table IV. CSR were measured in six subjects, five of whom were normal, during both control and DPH periods. An increase, of relatively small degree, was found in four of the six subjects. In one subject, G.B., there was an insignificant decrease and in the remaining subject, no change.

ACTH administration, Table $V$. ACTH gel was given to two normal subjects and patient F.J.

TABLE v

Effect of ACTH administration* on steroid excretion in urine before and during DPH ingestion

\begin{tabular}{|c|c|c|c|c|c|}
\hline \multirow[b]{2}{*}{ Subject } & \multirow[b]{2}{*}{ Study period } & \multicolumn{4}{|c|}{ Rise in 24-hour excretion (or ratio) above base linet } \\
\hline & & 6-OHF & $17-\mathrm{OHCS}$ & $\frac{6-\mathrm{OHF}}{17-\mathrm{OHCS}}$ & $17-\mathrm{KS}$ \\
\hline \multirow{7}{*}{$\begin{array}{l}\text { D.B. } \\
\text { J.B. } \\
\text { F.J. }\end{array}$} & & $m g$ & $m g$ & & $m g$ \\
\hline & Control & 7.73 & 66.1 & 0.08 & 21.0 \\
\hline & DPH, $300 \mathrm{mg} /$ day, 4 weeks & 20.6 & 49.4 & 0.18 & 12.2 \\
\hline & Control & 3.56 & 45.4 & 0.03 & 14.6 \\
\hline & $\mathrm{DPH}, 400 \mathrm{mg} /$ day, 5 weeks & 20.59 & 67.7 & 0.16 & 15.4 \\
\hline & Control & 2.75 & 28.0 & 0.04 & 3.8 \\
\hline & $\mathrm{DPH}, 300 \mathrm{mg} /$ day, 3 weeks & 27.41 & 34.8 & 0.22 & 2.9 \\
\hline
\end{tabular}

* ACTH gel, $40 \mathrm{U}$ im at 9 a.m. and 1 p.m.

$\dagger$ The base-line excretions and ratios used in the compilation of these data were the averages for the respective study periods as depicted in Table I. 
TABLE VI

Steroid excretion in patients with convulsive seizures receiving long-term DPH therapy

\begin{tabular}{lccc}
\hline \hline & \multicolumn{3}{c}{ 24-hour steroid excretions } \\
\cline { 2 - 4 } & 6 -OHF & 17 -OHCS & $\frac{6-\mathrm{OHF}}{17-\mathrm{OHCS}}$ \\
\hline & $m g$ & $m g$ & \\
$\begin{array}{l}\text { Patients on DPH } \\
\text { Mean } \\
\text { Range }\end{array}$ & 1.57 & 3.2 & 0.65 \\
$\begin{array}{l}\text { Normal } \dagger \\
\text { Mean } \\
\text { Range }\end{array}$ & $1.01-3.01$ & $1.4-5.2$ & $0.20-1.37$ \\
& 0.40 & 7.3 & 0.06 \\
\hline
\end{tabular}

* Six male patients: one, age 5 (Cincinnati Children's Hospital), the remainder, ages 39 to 69 . DPH had been ingested from 6 months to 8 years at an average daily dosage of 100 to $400 \mathrm{mg}$. Five patients were receiving phenobarbital also.

$\dagger$ Fourteen males, ages 23 to 75 .

The increases in output of 6-OHF after ACTH were markedly augmented while the subjects were receiving DPH. The ratios of $6-\mathrm{OHF}$ : 17-OHCS also were enhanced considerably. A slightly greater increase in excretion of $17-\mathrm{OHCS}$ was found in subjects J.B. and F.J. These changes, coupled with the considerably higher increase in output of $6-\mathrm{OHF}$, indicate a greater adrenal secretory responsiveness in these two subjects when receiving $\mathrm{DPH}$.

Finally, steroid excretion was measured in 6 additional patients with convulsive disorders who had received long-term DPH treatment, in contrast to the previously mentioned 11 subjects. Output of 6-OHF was increased above normal (Table VI), the degree of which was comparable to that found in the subjects on short-term DPH treatment (Table I). Output of 17-OHCS, conversely, was in the low normal range. Ratios of 6-OHF : 17-OHCS were markedly abnormal, ranging from 0.20 to 1.37 , the degree of which tended to be greater than in normal subjects receiving short-term DPH.

\section{Discussion}

The principal results of this investigation document an extra-adrenal alteration in cortisol metabolism induced by administration of $\mathrm{DPH}$ to human subjects. The alteration was characterized by an increased proportion of cortisol metabolized to polar unconjugated metabolites and a corresponding decreased proportion metabolized via A-ring reduction and glucuronic acid conjugation. The polar unconjugated metabolites consisted principally of 6-OHF, and in somewhat lesser amounts, another, as yet unidentified, polar compound. Interestingly, the alteration in tetrahydro derivatives included an increase in the proportion of THF to THE and to the total tetrahydro metabolites.

The major alterations were observed in radioactive metabolites in urine after administration of cortisol-4-C $\mathrm{C}^{14}$ in vivo, indicating that the changes truly reflected metabolism of cortisol. Furthermore, the changes were found in one patient with Addison's disease and in another bilaterally adrenalectomized, indicating that the metabolic alterations occurred outside of the adrenal glands. Presumably the major site is liver, since it is well known to be the chief organ responsible for the greatest proportion of cortisol metabolism. Also the study by Lipman, Katz, and Jailer, employing human tissue incubation in vitro, demonstrated more $6 \beta$-hydroxylation activity in liver than in other tissues $(23)$.

That other steroids may have been altered by $\mathrm{DPH}$ administration was suggested by reduction in $17-\mathrm{KS}$ excretion. Since neither the radioactive $17-\mathrm{KS}$ metabolites of cortisol (Table II) nor the $17-\mathrm{KS}$ in adrenalectomized patient W.G. appeared to change, we suggest that the observed reduction in $17-\mathrm{KS}$ in the normal subjects involved adrenal 11-deoxy 17-KS, e.g., dehydroisoandrosterone.

CSR did not change consistently after DPH administration to normal subjects. It was suggested that cortisol secretion may increase to a variable degree during 4 to 8 weeks of $\mathrm{DPH}$ treatment, as manifested by CSR results in four subjects and the urinary excretion steroid values in patient F.J. Responses to ACTH in two subjects, as manifested by increased excretion of 17 OHCS plus 6-OHF, also suggested adrenal hyperactivity. Previous studies of the effect of $\mathrm{ACTH}$ in subjects treated with $\mathrm{DPH}$ have suggested either normal $(8,9)$ or reduced (9) adrenocortical responsiveness. However, techniques employed were considerably different from ours. Specifically, 24-hour total excretion of 17-OHCS and $6-\mathrm{OHF}$ in short-term treated subjects was not determined.

The disparity, in short-term DPH-treated subjects, between possible adrenal hypersecretion and 
the previously reported reduced responsiveness to methopyrapone (10) cannot be explained. Further study is necessary to clarify this point.

Patients with convulsive disorders receiving prolonged DPH therapy from 6 to 8 years (Table VI) demonstrated the alteration in ratio of 6-OHF : 17-OHCS similar to that in the experimental subjects treated up to 8 weeks with $\mathrm{DPH}$. Low output of 17-OHCS in this group, however, suggested a decrease in cortisol secretion despite the increase in 6-OHF excretion. This pattern of an eventual decrease in cortisol secretion after an initial increase with DPH treatment has been suggested previously by Costa, Glaser, and Bonnycastle (7).

An incidental but important finding was that urine from subjects treated with $\mathrm{DPH}$ requires a greater concentration of $\beta$-glucuronidase than usual to achieve maximal hydrolysis of steroidglucuronide conjugates. This indicates an inhibition of $\beta$-glucuronidase by DPH or its major metabolite, 5-( $p$-hydroxyphenyl)-5-phenylhydantoin (24), which is conjugated with glucuronic acid (25). Although the mechanism of inhibition was not studied, it is conceivable that it might be a competitive one as noted with the glucuronide of acetylsalicylic acid (26). In any event it is important to know that the concentration of $\beta$-glucuronidase must be increased when analyzing for 17-OHCS in urine from DPH-treated patients. Failure to do so results in values for $17-\mathrm{OHCS}$ approximately $45 \%$ too low and would partially discredit some low levels reported after DPH (8) but not others (7) where enzyme hydrolysis was not employed.

The mechanism of the increased excretion of $6-\mathrm{OHF}$ is not clear. Considerable information regarding this metabolite has been contributed recently in a series of studies by Frantz, Katz, Jailer, Lipman, and Borkowski (11, 12, 16, 23, 27) and by Ulstrom, Colle, Burley, and Gunville (13). The latter group noted that $6-\mathrm{OHF}$ was a major metabolite of cortisol in newborn infants. The former group initially observed an increased output of 6-OHF in pregnancy and subsequently attributed increased formation of 6-OHF to inhibition of cortisol A-ring reduction brought about by a high level of estrogen and a resultant interference with TPNH production.

The finding in the current study of a propor- tionate decrease in tetrahydro derivatives is consistent with the postulate of a partial block in A-ring reduction. It does not seem likely, however, that this aberration is due to an estrogenic effect, since after DPH therapy there is no increase in plasma cortisol binding, as shown by normal levels of $17-\mathrm{OHCS}$ in plasma $(8,9)$.

Effects of other hormones, testosterone, ACTH, and thyroxine, might be considered. Testosterone depresses cortisol A-ring reduction (28-30) but does not increase 6-OHF excretion (11). ACTH has been reported to enhance 6-OHF excretion to some degree (16). In the present study, however, little change was noted in the ratio of 6-OHF : 17-OHCS after ACTH when subjects were not receiving DPH. Thyroxine is known to be displaced by $\mathrm{DPH}$ from thyroxine-binding globulin (31), but an excess of thyroxine would be expected to increase the proportion of $\mathrm{THE}$ rather than reduce it.

Thus current evidence indicates that the alteration in cortisol metabolism induced by $\mathrm{DPH}$ is not mediated through effects by these hormones. Perhaps DPH, or its major metabolite (24), may interfere directly with cortisol A-ring reduction or TPNH production.

Whether there is any relation between pharmacological action of DPH and this aberration in cortisol metabolism remains speculative. Levels of $17-\mathrm{OHCS}$ in plasma are normal during $\mathrm{DPH}$ therapy $(8,9)$. Conceivably DPH might interfere with cortisol metabolism in brain as well as liver. Such a concept would require a reduction in cortisol activity locally, since cortisol enhances brain excitability. How this could occur in conjunction with the metabolic alteration is questionable. It is of interest, however, that other known effects of DPH are consistent with a reduction in cortisol activity, namely, lymphoid hyperplasia (32, 33), protein anabolism (34), dermal chemical response (35), and a suggestion of amelioration of Cushing's syndrome despite high levels of $17-\mathrm{OHCS}$ in urine (36).

\section{Summary}

The effect of diphenylhydantoin administration on cortisol metabolism was investigated in human subjects by analyzing cortisol metabolites in urine. Diphenylhydantoin caused a net increase in ex- 
cretion of 6-hydroxycortisol and an unconjugated polar metabolite concomitant with a relative decrease in conjugated tetrahydro derivatives. Similar results were found in two patients with adrenal insufficiency. Fractionation studies after administration of cortisol-4-C $\mathrm{C}^{14}$ to subjects treated with diphenylhydantoin confirmed these changes and demonstrated them to be the major alterations in cortisol metabolism induced by diphenylhydantoin.

Administration of exogenous ACTH enhanced the alteration in cortisol metabolism in diphenylhydantoin-treated subjects.

Cortisol secretion rates increased slightly in four of six subjects treated with diphenylhydantoin for 5 to 8 weeks. In addition, one patient with brain trauma showed a marked increase in steroid excretion indicative of a true rise in cortisol secretion. In other patients receiving longterm diphenylhydantoin therapy cortisol secretion appeared to be reduced.

Output of total 17-ketosteroids decreased slightly in normal subjects receiving diphenylhydantoin but not in patients with adrenal insufficiency, which suggested an effect on the metabolism of 11-deoxy, 17- ketosteroids produced in the adrenals.

An incidental but important finding in the study was that of an in vitro inhibition of $\beta$-glucuronidase in urine from subjects receiving diphenylhydantoin. Thus a fourfold increase in enzyme concentration was necessary in these samples for maximal hydrolysis, compared to control urine samples.

We conclude that diphenylhydantoin alters extra-adrenal metabolism of cortisol and probably 17-ketosteroids as well. This effect may be related to the pharmacological activity of diphenylhydantoin.

\section{Acknowledgments}

The authors gratefully acknowledge the excellent technical assistance of Margaret Ehrhart, Theresa Hughes, John Lindsley, Kay Myers, and Brandon Taylor. We wish to thank Dr. Seymour Bernstein, Organic Chemical Research Section, Lederle Laboratories, Pearl River, N. Y., for the samples of pure $6 \beta$-hydroxycortisol and $6 \alpha$-hydroxycortisol.

\section{References}

1. Werk, E. E., Jr., L. J. Sholiton, J. MacGee, and R. T. Marnell. Altered cortisol metabolism in advanced cancer. Clin. Res. 1962, 10, 300.
2. Woodbury, D. M., P. S. Timiras, and A. Vernadakis. Influence of adrenocortical steroids on brain function and metabolism in Hormones, Brain Function, and Behavior, H. Hoagland, Ed. New York, Academic Press, 1957, p. 27.

3. Goncharov, N. P. The effect of substances stimulating and depressing the central nervous system on the quantity and quality of corticosteroids in the blood of dogs and guinea pigs. Bull. exp. Biol. Med. 1962, 52, 1295 .

4. Staple, P. H. Diphenylhydantoin, adrenal function and epilepsy (abstract). J. Endocr. 1953, 9, XVIII.

5. Bonnycastle, D. D., and A. J. Bradley. Diphenylhydantoin and the release of adrenocorticotropic hormone in the albino rat. Endocrinology 1960, 66, 355 .

6. Glaser, G. H. On the relationship between adrenal cortical activity and the convulsive state. Epilepsia (Boston) 1953, $2,7$.

7. Costa, P. J., G. H. Glaser, and D. D. Bonnycastle. Effects of diphenylhydantoin (Dilantin) on adrenal cortical function. Arch. Neurol. Psychiat. (Chic.) 1955, 74, 88.

8. Bray, P. F., R. S. Ely, G. Zapata, and V. C. Kelley. Adrenocortical function in epilepsy. I. The role of cortisol (hydrocortisone) in the mechanism and management of seizures. Neurology (Minneap.) 1960, 10, 842.

9. Christy, N. P., and A. D. Hofmann. Effects of diphenylhydantoin upon adrenal cortical function in man. Neurology (Minneap.) 1959, 9, 245.

10. Krieger, D. T. Effect of diphenylhydantoin on pituitary-adrenal interrelations. J. clin. Endocr. 1962, 22, 490.

11. Katz, F. H., M. M. Lipman, A. G. Frantz, and J. W. Jailer. The physiologic significance of $6 \beta$-hydroxycortisol in human corticoid metabolism. J. clin. Endocr. 1962, 22, 71.

12. Frantz, A. G., F. H. Katz, and J. W. Jailer. 6-Betahydroxycortisol: high levels in human urine in pregnancy and toxemia. Proc. Soc. exp. Biol. (N. Y.) 1960, 105, 41.

13. Ulstrom, R. A., E. Colle, J. Burley, and R. Gunville. Adrenocortical steroid metabolism in newborn infants. II. Urinary excretion of $6 \beta$-hydroxycortisol and other polar metabolites. J. clin. Endocr. 1960, 20, 1080.

14. Silber, R. H., and C. C. Porter. The determination of 17,21-dihydroxy-20-ketosteroids in urine and plasma. J. biol. Chem. 1954, 210, 923.

15. Romanoff, L. P., R. M. Rodriguez, J. M. Seelye, C. Parent, and G. Pincus. The urinary excretion of tetrahydrocortisol, $3 \alpha$-allotetrahydrocortisol and tetrahydrocortisone in young and elderly men and women. J. clin. Endocr. 1958, 18, 1285.

16. Frantz, A. G., F. H. Katz, and J. W. Jailer. $6 \beta-$ Hydroxycortisol and other polar corticosteroids: measurement and significance in human urine. J. clin. Endocr. 1961, 21, 1290. 
17. Kittinger, G. W. The determination of adrenal cortical $\alpha$-ketolic steroids by quantitative paper chromatography. J. Lab. clin. Med. 1960, 55, 796.

18. Drekter, I. J., A Heisler, G. R. Scism, S. Stern, S. Pearson, and T. H. McGavack. The determination of urinary steroids. I. The preparation of pigment-free extracts and a simplified procedure for the estimation of total 17-ketosteroids. J. clin. Endocr. 1952, 12, 55.

19. Folin, O., and H. Wu. System of blood analysis. J. biol. Chem. 1919, 38, 81.

20. Glenn, E. M., and D. H. Nelson. Chemical method for the determination of 17-hydroxycorticosteroids and 17 -ketosteroids in urine following hydrolysis with $\beta$-glucuronidase. J. clin. Endocr. 1953, 13, 911.

21. Flood, C., D. S. Layne, W. Ramcharan, E. Rossipal, J. F. Tait, and S. A. S. Tait. An investigation of the urinary metabolites and secretion rates of aldosterone and cortisol in man and a description of methods for their measurement. Acta endocr. (Kbh.) 1961, 36, 237.

22. Murray, F. J. Outbreak of unexpected reactions among epileptics taking isoniazid. Amer. Rev. resp. Dis. 1962, 86, 729.

23. Lipman, M. M., F. H. Katz, and J. W. Jailer. An alternate pathway for cortisol metabolism: $6 \beta$-hydroxycortisol production by human tissue slices. J. clin. Endocr. 1962, 22, 268.

24. Butler, T. C. The metabolic conversion of 5,5-diphenylhydantoin to 5-( $p$-hydroxyphenyl) -5 -phenylhydantoin. J. Pharmacol. exp. Ther. 1957, 119, 1.

25. Maynert, E. W. The metabolic fate of diphenylhydantoin in the dog, rat and man. J. Pharmacol. exp. Ther. 1960, 130, 275.

26. Stempfel, R. S., Jr., J. B. Sidbury, Jr., and C. J. Migeon. $\beta$-Glucuronidase hydrolysis of urinary corticosteroid conjugates: the effect of salicylate glucuronoside as a competing substrate and the effect of enzyme inactivation. J. clin. Endocr. 1960, 20, 814.
27. Borkowski, A. J., P. A. Marks, F. H. Katz, M. M. Lipman, and N. P. Christy. An abnormal pathway of steroid metabolism in patients with glucose-6phosphate dehydrogenase deficiency. J. clin. Invest. 1962, 41, 1346.

28. Yates, F. E., A. L. Herbst, and J. Urquhart. Sex difference in rate of ring $\mathrm{A}$ reduction of $\Delta^{4}-3$-ketosteroids in vitro by rat liver. Endocrinology 1958, $63,887$.

29. Hagen, A. A., and R. C. Troop. Influence of age, sex and adrenocortical status on hepatic reduction of cortisone in vitro. Endocrinology 1960, 67, 194.

30. Kumagai, A., M. Otomo, S. Yano, N. Takeuchi, K. Nishino, H. Ueda, S. Ko, and M. Kitamura. Inhibition of cortisol metabolism in the liver by other steroids. Endocr. jap. 1959, 6, 86.

31. Oppenheimer, J. H., and R. R. Tavernetti. Studies on the thyroxine-diphenylhydantoin interaction: effect of 5,5'-diphenylhydantoin on the displacement of L-thyroxine from thyroxine-binding globulin (TBG). Endocrinology 1962, 71, 496.

32. Saltzstein, S. L., and L. V. Ackerman. Lymphadenopathy induced by anticonvulsant drugs and mimicking clinically and pathologically malignant lymphomas. Cancer (Philad.) 1959, 12, 164.

33. Rosenfeld, S., A. I. Swiller, Y. M. V. Shenoy, and A. N. Morrison. Syndrome simulating lymphosarcoma induced by diphenylhydantoin sodium. J. Amer. med. Ass. 1961, 176, 491.

34. Robinson, W. A., W. A. Engle, and D. L. Smith. Effect of diphenylhydantoin sodium on liver restitution in the rat following hepatectomy. Proc. Soc. exp. Biol. (N. Y.) 1962, 111, 477.

35. Houck, J. C., and R. A. Jacob. Connective tissue VII. Factors inhibiting the dermal chemical response to cortisol. Proc. Soc. exp. Biol. (N. Y.) 1963, 113, 692.

36. Clinicopathologic Conference, Washington University School of Medicine. Cushing's syndrome associated with parotid gland tumor. Amer. J. Med. 1963, 34, 394. 